\title{
Citação com hora certa
}

\author{
Gabriel de Rezende Filho
}

Natureza da decisão que rejeita requerimento do réu, de nulidade de citação com hora certa. Si cabe agravo dessa decisão com fundamento em dano irreparavel.

\section{PARECER}

Ante a exposição da consulta e dos anexos que a acompanharam, respondemos aos quesitos formulados pela maneira seguinte:

\section{Ao primeiro}

Foi legal a citação com hora certa, feita a L., na pessôa de sua mulher e no domicílio do casal, em face do que dispõe o Código de Processo do Estado de Pernambuco, no seu L. I, Cap. II, Tit. I, especialmente nos arts. 182 e 183.

O fim da citação inicial é fazer ciente o réu de que contra ele vai ser proposta determinada ação.

Variam, porém, os meios de ser atingido esse fim.

Embora a citação deva ser feita na pessoa do réu, admite a lei a citação presumida ou ficta, quando haja impossibilidade de ser encontrado o citando. 
Subsidiária da citação pessoal, a chamada cítação com hora certa constitúe a providência legal para o caso em que o citando se oculte afim de evitar a citação.

Provém das Ords., L. 30, I, § 9.:

“ . deve ser feita a citação em pessôa do citado e não de outra maneira, salvo quando o juiz da causa fôr em verdadeiro conhecimento por inquirição que o que havia de ser citado se escondeu ou ausentou por não ser citado, de maneira que não pode ser encontrado.

O reg. 737 , todavia, ao disciplinar, no art. 46 , a citação com hora certa, aludiu ao fato da ocultação, não se referindo á ausência do citando.

E os códigos estaduais - entre eles, o de Pernambuco -. nada mais fizeram que repetir a doutrina do reg. 737.

Tem-se entendido que, ausente o citando de seu domirilio. e certificado o fáto pelos oficiais de justiça, encarregados da diligência, de duas uma: ou o citando se encontra em lugar certo, fóra da circunscrição do juiz da causa, e, nesse caso, a citação deve ser feita por meio de precatória; ou se acha em lugar incerto, e já aí cumpre serem expedidos os editais de citação.

A citação com hora certa, em suma, só é admissivel quando o réu se oculta maliciosamente, afim de furtar-se á citação pessoal.

A regularidade desse meio subsidiário de ‘itação depende do estrito cumprimento das formalidades, adréde estabelecidas pela lei para obviar possiveis abusos.

Tudo repousa, afinal, na fé que merecem as certidôes dos of iciais, incumbidos da diligência.

Uma vez que estes auxiliares da justiça se convencem da malícia do citando, que se esquiva de recebê-los, podem, independentemente de despacho especial do juiz, proceder á citação com hora certa. 
A lei deve atender - como bem salienta MORTARA aos casos em que se torna impossivel citar o réu em su: pessôa, estabelecendo outras modalidades de citacão, e se contenta, então, com a certeza (legal, e não real), de cue esse áto judicial alcancará o seu fím específico - o de levar ao conhecimento do citando que contra ele será intentada determinada ação.

No caso em apreço, á vista da exposição da consulta e dos anexos, especialmente da cópia da sentença que indeferiu o requerimento do réu L., de nulidade da citação com hora certa, que lhe fôra feita, parece-nos que só era possivel essa modalidade de citação.

Com efeito, a malícia do réu, que, obstinadamente, se esquivava á citação pessoal, decorria de vários fátos.

$\mathrm{Na}$ iminência de vêr propósta contra ele a ação rescisória, cuja prescrição estava prestes a consumar-se, resolvera ausentar-se ou simulara ausentar-se da Capital, onde tinha o seu domicilio.

Daí por diante, o seu paradeiro foi inconstante.

Teria telegrafado (ou mandado telegrafar) da cidade de R. B., a pessôas de destaque da Capital, para, lógo após, de outra cidade - C., avisar telegraficamente aos autores e seus advogados de que se achava ciente de estar sendo procurado afim de ser citado para uma ação, cuja natureza desconhecia, indicando-lhes o lugar, e até mesmo a residência, onde poderia ser encontrado.

Os autores - providenciada a citação da mulher do réu, que permanecêra na Capital - apressaram-se em requerer a citação deste por meio de precatória, expedida ao juizo de C.

Nem só esta, como outra precatória, com o mesmo fim e ad cautelam requerida, lograram sucesso, porquanto, na alùdida comarca, não foi ele encontrado.

Tudo denotava, assim, a ilicitude do réu, procrastinando a sua citação. 
Na Capital, no domicilio do casal, os oficiais de justiça, por varias vezes, obtiveram informações da mulher do réu de que este não se achava em casa, marcando-lhes, ao mesmo tempo, outro dia ou outras horas para voltarem e se desempenharem de sua incumbência.

As circunstâncias impunham, assim, se fizesse a citação do réu com hora certa, na fórma da lei e com as solenidades por esta prescritas.

\section{Aos segundo e terceiro, conjuntamente}

De outro modo não podiam agir os autores.

Tentaram, a principio, o expediente da precatória, fiados na palavra do réu, que lhes havia telegrafado, dizendo-se ciente de que o andavam procurando para ser citado e indicando-lhes lugar e residência em outra comarca.

Não vingando a precatória - porque o réu já não se encontrava mais na referida comarca - cumpria aos autores requerer a expedição de editais?

Como se sabe, essa fórma de citação é excepcional e só admissivel nos casos taxativos da lei.

Duas hipóteses autorizariam, na espécie, o edital:

a) encontrar-se o citando em lugar incerto;

b) ser inacessivel o lugar certo, onde estivesse.

Mas, o réu estava ausente, de fáto, em lugar incerto?

A sua mulher, que devia saber por onde ele andava, nunca disse aos oficiais de justiça que o seu marido se encontrasse fóra da Capital, antes lhes rogava voltassem em outro dia ou em outras horas para efetuarem a citação pessoal.

Como justificar-se, nestas circunstâncias, a ausência do réu em lugar incerto? 
A presunção legitima era a de que ele - mancomunado com a sua mulher - agia ilicitamente, burlava a justiça, evitando, por todos os meios, a sua citação para a ação rescisória.

\section{Ao quarto}

Não padece dúvida que ao juiz preparador de ação rescisória de julgado proferido por Tribunal de Apelação incumbe decidir os incidentes de ordem processual que ocorram na mesma ação.

Competia, por isso, ao juiz tomar conhecimento e decidir o requerimento do réu $L$, de nulidade da citação com hora certa.

Essa sentença era ordinatória do feito.

Ensinam todos os praxistas que as sentenças se dividem em definitivas e interlocutórias.

A sentença definitiva é a declaração solene do direito controvertido, ao passo que a sentença interlocutória è a decisão do juiz sobre incidentes da causa.

Resolve aquela a questão principal, que deu causa á lide, enquanto esta põe termo apenas a questões incidentes ou emergentes no curso da mesma lide.

Os escritores modernos, usando de outra terminologia, aludem ás sentenças de fórma e de mérito.

As decisões de fórma referem-se a nulidades processuais, como as que apreciam a legitimidade das partes, a sua representação em juizo, questões prévias, como a incomnetência ou a suspeição do juiz, a ineptidão do libelo, a falta ou as irregularidades da citação, o emprêgo de fórma processual inadequada, a falta de intervenção do Ministério Público e outras desse jaez.

Visam a regularização do processo ou da instância, escoimando o feito de vícios de fórma, antes de ser proferida na causa a sentença definitiva. 
As decisões de mérito atingem o fundo da causa, resolvem a questão principal.

Ora, a sentença, que examinamos, não passava, iniludivelmente, de uma decisão de fórma, ordinatória do feito, que não exorbitava da competência do juiz inferior para "processar e preparar" a ação rescisória, cujo "julgamento" é reservado por lei ao Tribunal de Apelação.

Decidisse o juiz, como decidiu, pela validade da citação do réu. mandando prosseguir no feito, ou decidisse. de revés, pela nulidade daquele áto, absolvendo. em consequência, o réu da instância - não estaria prejulgando, ou julgando a ação rescisória, mas, pondo termo a um incidente processual.

\section{Ao quinto}

Com o seu requerimento, o réu L. visava a decretação da nulidade da citação com hora certa, que lhe fôra feita.

Alegava que da rescisória só tivera conhecimento, quando fôra novamente citado para a renovação da instância, paralizada com o falecimento de um dos co-autores, mas já sem tempo de poder defender-se, uma vez que estava esgotado o prazo para a contestação.

Indeferido o seu requerimento, agravou da sentença para o Tribunal de Apelação, fundando o seu recurso, não só no n. 2 do art. 1.468 do Código de Processo (agravo de decisão sobre matéria de competência), como no n. 66 do mesmo artigo (agravo de decisão que contenha dano de natureza irreparavel).

Estudemos, como pede o quesito, si a sentença em questão teria causado ao réu dano irreparavel.

O texto do n. 66 do citado art. 1.468 é o seguinte: 
“Além dos casos previstos neste Código e em leis especiais, caberá agravo da decisão interlocutória que, contrariando disposição expressa de lei, contivér dano de natureza irreparavel, considerando-se tal o que, por ocasião do julgamento do feito em qualquer instância, não puder, em absoluto, ser reparado, ou sómente puder sê-lo com grande e inevitavel prejuizo".

Do dispositivo transcrito decorre que o agravo, com fundamento no dano irreparavel, só se justifica:

a) quando a decisão agravada contrariou disposiçâo expressa de lei;

b) e, em consequência, causou dano de natureza irreparavel.

Faltando uma dessas condições, o agravo não procede.

A sentença, que apreciamos, teria contrariado alguma disposição expressa de lei? Qual?

Segundo nos parece, o juiz cumpriu, e não contrariou a lei, ao decidir o requerimento do réu.

Com efeito, em primeiro lugar, era de sua competência essa decisão.

Além disso, ao proferir a sentença, depois de esmiuçar os elementos de prova oferecidos por ambos os litigantes, deu, afinal, as razões de sua convicção, mantendo a citação com hora certa. a seu vêr legitima, perfeitamente adequada ao caso.

Si o réu. pois, foi citado sob pena de revelia. e não compareceu em juizo para defender-se. deve sofrer as consequências de seu procedimento.

O dano, na espécie, é de natureza irreparavel, sem dúvida alguma, porque não the é dado mais oferecer contestação e produzir provas casuais. 
Mas, o dano não adveiu da sentença, repelindo a sua pretensão ilegitima, e sim, de sua propria atitude, não vindo a juizo defender-se no prazo legal.

E' o nosso parecer, s. m. j.

S. Paulo, 15 de outubro de 1939. 